\title{
An updated classification of the phylum Nemertea
}

\begin{abstract}
A.V. Chernyshev
A.V. Zhirmunsky National Scientific Center of Marine Biology, Far Eastern Branch, Russian Academy of Sciences, Vladivostok 690041, Russia.E-mail: nemertea1969@gmail.com

Far Eastern Federal University, Vladivostok 690600, Russia.

ABSTRACT: A higher-level classification of Nemertea has been updated based on insights from recent phylogenetic studies. According to this classification, the phylum includes two superclasses (Pronemertea and Neonemertea), three classes (Palaeonemertea, Pilidiophora, and Hoplonemertea), and eight orders. The order Arhynchonemertea is considered as an incertae sedis taxon. For all taxa above the family level, diagnoses and synapomorphies are provided.

How to site this article: Chernyshev A.V. 2021. An updated classification of the phylum Nemertea // Invert. Zool. Vol.18. No.3. P.188-196. doi: 10.15298/invertzool.18.3.01
\end{abstract}

KEY WORDS: nemerteans, phylogeny, diagnoses.

\section{Обновленная система типа Nemertea}

\begin{abstract}
А.В. Чернышев
Национальный научный центр морской биологии им. А.В. Жирмунского ДВО РАН, Владивосток 690041, Россия. E-mail: nemertea1969@gmail.com

Дальневосточный федеральный университет, Владивосток 690600, Россия.

РЕЗЮМЕ: Представлена система высших таксонов Nemertea, которая отражает современные данные о филогении этого типа. Согласно этой классификации, тип включает два надкласса (Pronemertea и Neonemertea), три класса (Palaeonemertea, Pilidiophora и Hoplonemertea) и восемь отрядов. Отряд Arhynchonemertea отнесен к таксонам incertae sedis. Для всех таксонов выше семейства приведены диагнозы и указаны синапоморфии.

Как цитировать эту статью: Chernyshev A.V. 2021. An updated classification of the phylum Nemertea // Invert. Zool. Vol.18. No.3. P.188-196. doi: 10.15298/invertzool. 18.3.01
\end{abstract}

КЛЮЧЕВЫЕ СЛОВА: немертины, филогения, диагнозы.

The paper is devoted to 70th anniversary of Prof. V.V. Malakhov.

Статья посвящена 70-летию со дня рождения проф., акад. В.В. Малахова. 


\section{Introduction}

Nemerteans, or ribbon worms, are unsegmented, vermiform spiralians distinguished by their unique eversible proboscis (excepting $\mathrm{Ar}$ hynchonemertes axi Riser, 1988) located in the coelom-like rhynchocoel. The phylum Nemertea comprises 1340 marine, brackish-water, freshwater, and terrestrial species (Gibson, 1995; Kajihara et al., 2008; WoRMS). Nemerteans are extremely variable in their appearance (Fig. 1), with their body size ranging from $3 \mathrm{~mm}$ to 40-50 m. For quite a long time, the nemertean classification strictly followed the modified Stiasny-Wijnhoff division (Wijnhoff, 1913; Stiasny-Wijnhoff, 1936) of the taxon into two classes (Anopla and Enopla) and four orders (Palaeonemertea, Heteronemertea, Hoplonemertea, and Bdellonemertea). In 19th-20th centuries, other classifications of this phylum were also proposed (Bürger, 1892; Gibson, 1982, 1988; Sundberg, 1991; Crandall, 1993; Chernyshev, 1995), but a revision of the traditional system has become possible only in the $21 \mathrm{st}$ century, with the use of molecular phylogenetic methods of analysis (Tholleson, Norenburg, 2003; Andrade et al., 2012, 2014; Kvist et al., 2014, 2015; Chernyshev, Polyakova, 2018, 2019). First, the division of nemerteans into the classes Anopla and Enopla has been re-evaluated, with a system consisting of three classes, Palaeonemertea, Pilidiophora, and Hoplonemertea, proposed instead (see Strand et al., 2019). So far, there is no commonly accepted classification within these classes, although phylogenetic relationships between the orders are generally identified (Fig. 2). A classification of the phylum Nemertea on the family level and above, which takes into account the latest views on the phylogeny of this phylum, is presented in this report.

\section{Systematic part}

\section{PHYLUM NEMERTEA (=RHYNCHOCOELA)}

Superclass PRONEMERTEA supercl.n.

DIAGNOSIS. Middorsal blood vessel absent. Frontal organ absent.
Class Palaeonemertea Hubrecht, 1879

DIAGNOSIS. Epidermis of palaeonemertean type. Brain and lateral nerve cords basiepidermal, subepidermal (located between dermis and body-wall outer circular musculature), or intramuscular (located in body-wall longitudinal musculature). Proboscis biradial or bilateral, with diagonal musculature. Pseudocnidae present or absent. Cerebral organs absent, epidermal, or slightly submerged into body musculature. Spermatozoa with one ring-shaped mitochondrion. Planula-like larva.

SYNAPOMORPHIES. No synapomorphies for Palaeonemertea have been identified to date, although the monophyly of this class is confirmed by molecular phylogenetic analyses (Andrade et al., 2014; Kvist et al., 2014). The epidermal ('tubulanid') ring, which is present in Carininidae and Tubulanidae and, apparently, disappeared in Carinomidae and Archinemertea, can be a probable synapomorphy. Yurchenko et al. (2021) recently suggested that the offset acrosomal complex of the sperm head may be a synapomorphic trait of palaeonemerteans.

Order Carinomiformes Chernyshev, 1995

DIAGNOSIS. Epidermal ('tubulanid') ring in nephridial region absent (Carinomidae) or present (Carininidae). Body wall consists of outer circular, diagonal, middle longitudinal, and inner circular muscle layers; additional outer longitudinal musculature present in cerebral and foregut regions of Carinomidae. Brain and lateral nerve cords located basiepidermally (Carininidae) or between dermis and body-wall outer circular musculature; in intestine region, lateral nerve cords submerged into body-wall longitudinal musculature (Carinomidae). Cerebral organs absent or present. Nephridia with glandular mass inside lateral blood vessels and with pair of longitudinal collecting tubules. Proboscis with type I pseudocnidae or pseudocnidae absent. Lateral organs absent. Larva with single midventral eye.

SYNAPOMORPHIES. Single midventral eye in larva.

COMPOSITION. Two families, Carinomidae Bergendal, 1900 and Carininidae Chernyshev, 2011. 

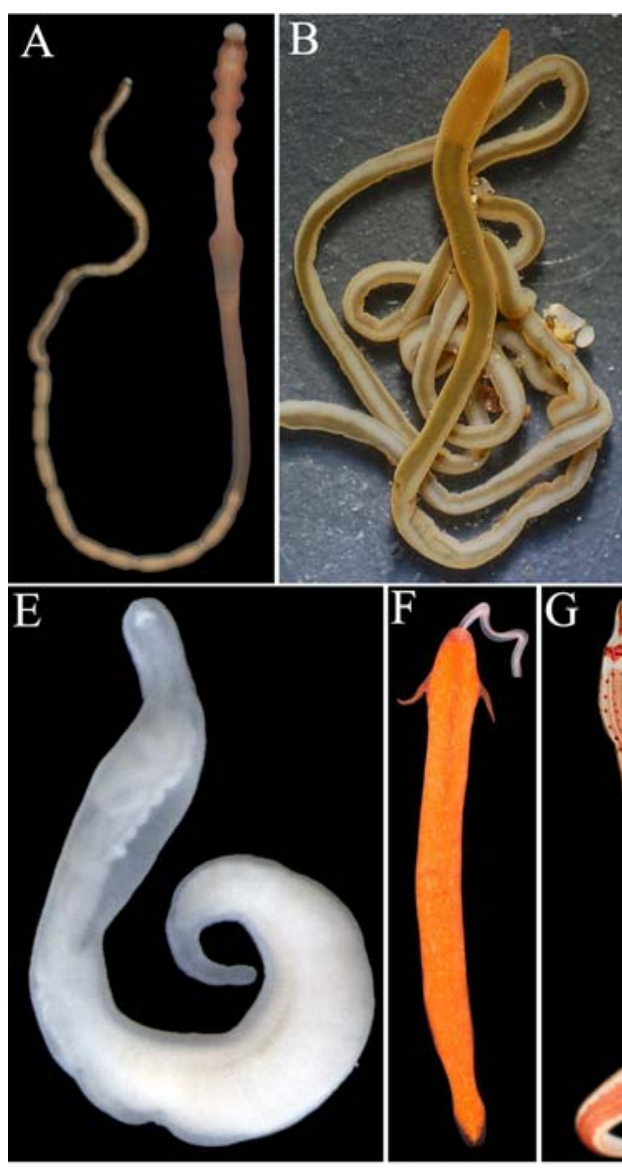
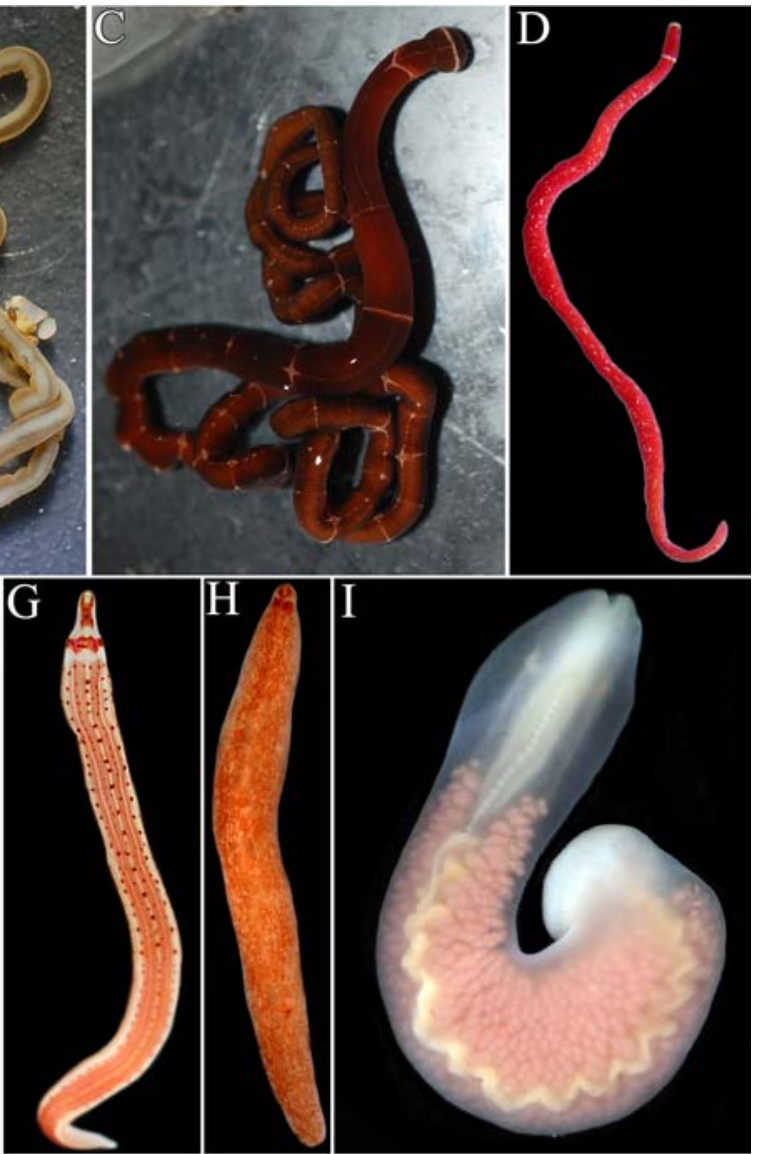

Fig. 1. Habitus of selected species of nemerteans from different orders. Photographs of live animals. A Carinina yushini (Palaeonemertea: Carinomiformes); B - Cephalothrix mokievskii (Korotkevitsch, 1982) (Palaeonemertea: Archinemertea); C - Tubulanus punctatus (Takakura, 1898) (Palaeonemertea: Tubulaniformes); D - Kulikovia manchenkoi Chernyshev, Polyakova, Turanov et Kajihara, 2017 (Pilidiophora:Heteronemertea); E-Hubrechtellajuliae Chernyshev, 2003 (Pilidiophora: Hubrechtiiformes); F-Nectonemertes cf. mirabilis Verrill, 1892 (Hoplonemertea: Polystilifera); G - Drepanophoridae gen. sp. (Hoplonemertea: Polystilifera); H - Nipponnemertes arenaria (Uschakov, 1927) (Hoplonemertea: Monostilifera: Cratenemertea); I - Malacobdella japonica Takakura, 1897 (Hoplonemertea: Monostilifera: Eumonostilifera).

Рис. 1. Внешний вид некоторых видов немертин из разных отрядов. Фотографии живых животных. A - Carinina yushini (Palaeonemertea: Carinomiformes); B - Cephalothrix mokievskii (Korotkevitsch, 1982) (Palaeonemertea: Archinemertea); C - Tubulanus punctatus (Takakura, 1898) (Palaeonemertea: Tubulaniformes); D - Kulikovia manchenkoi Chernyshev, Polyakova, Turanov et Kajihara, 2017 (Pilidiophora:Heteronemertea); E-Hubrechtellajuliae Chernyshev, 2003 (Pilidiophora:Hubrechtiiformes); F-Nectonemertes cf. mirabilis Verrill, 1892 (Hoplonemertea: Polystilifera); G — Drepanophoridae gen. sp. (Hoplonemertea: Polystilifera); H - Nipponnemertes arenaria (Uschakov, 1927) (Hoplonemertea: Monostilifera: Cratenemertea); I - Malacobdella japonica Takakura, 1897 (Hoplonemertea: Monostilifera: Eumonostilifera). 


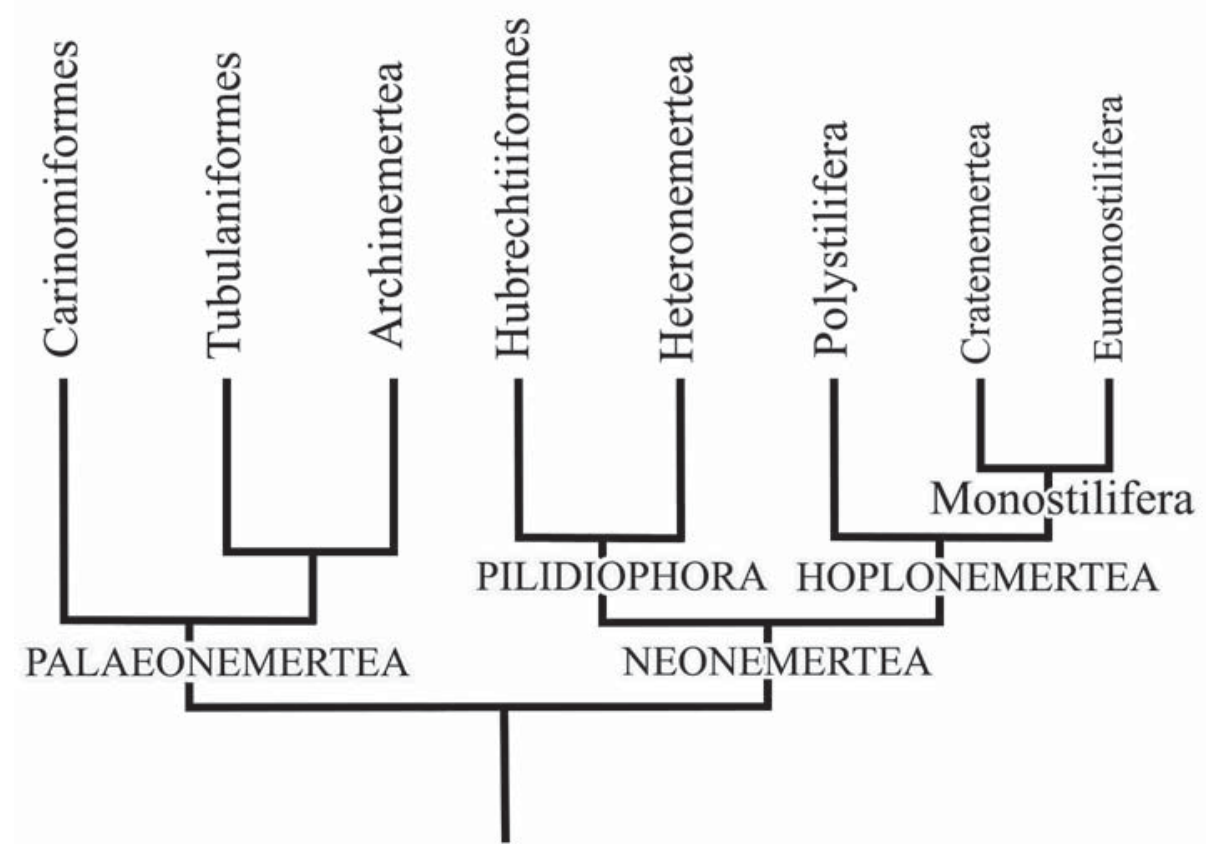

Fig. 2. Phylogenetic tree of Nemertea (modified after Andrade et al., 2014; Kvist et al., 2015; Chernyshev, Polyakova, 2019; Chernyshev et al., 2021).

Рис. 2. Филогенетическое дерево Nemertea (с изменениями по: Andrade et al., 2014; Kvist et al., 2015; Chernyshev, Polyakova, 2019; Chernyshev et al., 2021).

REMARKS. The name Carinomiformes was proposed as a suborder of Palaeonemertea with the only family Carinomidae (Chernyshev, 1995). Subsequently, the rank of the suborder was raised to the order level (Chernyshev, 1999). The relationship between Carinomidae and Carininidae has been found recently (Chernyshev et al., 2021) and accepted in WoRMS, where both families are placed in the order Carinomiformes (Norenburg et al., 2021).

\section{Order Archinemertea Iwata, 1960}

DIAGNOSIS. Epidermal ('tubulanid') ring in nephridial region absent. Body wall consists of outer diagonal, outer circular, middle longitudinal, and inner circular muscle layers. Brain and lateral nerve cords located in body-wall longitudinal musculature. Cerebral organs absent. Nephridia absent or numerous, with each nephridium consisting of mushroom-shaped body and radial efferent duct. Lateral organs absent. Proboscis with type I pseudocnidae. Larva with pair of lateral eyes.

SYNAPOMORPHIES. Position of the brain and the lateral nerve cords in longitudinal body musculature; diagonal muscles located between dermis and outer circular muscle layer.

COMPOSITION. Two families, Cephalotrichidae McIntosh, 1874 and Cephalotrichellidae Chernyshev, 2011.

Order Tubulaniformes Chernyshev, 1995

DIAGNOSIS. Epidermal ('tubulanid') ring in nephridial region present. Body wall consists of outer circular, diagonal, middle longitudinal, and inner circular muscle layers. Brain and lateral nerve cords located between dermis and body-wall outer circular musculature; in Carinomellidae, lateral nerve cords submerged into body-wall longitudinal musculature in intestine region. Cerebral organs present or absent. Nephridia with glandular mass inside lateral 
blood vessels and with pair of longitudinal collecting tubules. Lateral organs present or absent. Proboscis with type II pseudocnidae. Larva lacks eyes.

SYNAPOMORPHIES. A probable synapomorphy of the order is the presence of lateral organs, which disappear in some species (Chernyshev, 2011). Type II pseudocnidae may be considered another probable synapomorphy (Magarlamov et al., 2021).

COMPOSITION. Two families, Tubulanidae Bürger, 1904 and Carinomellidae Chernyshev, 1995.

Superclass NEONEMERTEA Thollesson et Norenburg, 2003 emend. Chernyshev, 2011

DIAGNOSIS. Middorsal blood vessel present. Frontal organ(s) present or lost.

SYNAPOMORPHIES. Middorsal blood vessel.

REMARKS. The name Neonemertea was proposed by Thollesson and Norenburg (2003) without diagnosis or rank. Subsequently, Neonemertea was assigned the rank of subclass with a diagnosis (Chernyshev, 2011).

Class Pilidiophora Thollesson et Norenburg, 2003 emend. Kajihara, 2007

DIAGNOSIS. Mouth located posteriorly of brain. Many species with caudal cirrus. Epidermis of palaeonemertean (Hubrechtiifirmes) or heteronemertean (Heteronemertea) type. Brain and lateral nerve cords located outside of bodywall outer circular musculature. Proboscis bilateral, with diagonal musculature and without stylet apparatus in middle portion; many species have two or one muscle crosses. Pseudocnidae present or absent. Spermatozoa with 2-6 mitochondria. Pilidial larva.

SYNAPOMORPHIES. Pilidial larva and, apparently, caudal cirrus and spermatozoa with two and more mitochondria. A hypothesis has been proposed that the caudal cirrus in this class emerged as a provisional structure required for juveniles to attach to substrate (Chernyshev, 2011). Chernyshev (2015) considers the bilateral pattern of proboscis musculature with muscle crosses among the possible synapomorphies.
REMARKS. The name Pilidiophora was proposed as clade Hubrechtella + Heteronemertea with the synapomorphy 'pilidium larva' (Thollesson, Norenburg, 2003). Kajihara (2007) was the first who suggested considering this clade with the rank of class.

Order Hubrechtiiformes Chernyshev, 1995

DIAGNOSIS. Body-wall musculature consists of outer circular, diagonal, and longitudinal muscle layers; inner circular layer present in some species (outer longitudinal musculature present in posterior intestinal region of Sundbergia Gibson, 2002). Cutis absent. Brain and lateral nerve cords located between dermis and body-wall outer circular musculature. Monociliary sensory cells of proboscis without apical cylinder.

SYNAPOMORPHIES. No synapomorphies can be found for this order so far. An unusual arrangement of muscular layers in the proboscis, which has two layers of diagonal musculature and lacks outer circular musculature, has been described from Hubrechtella Bergendal, 1902 (Chernyshev et al., 2013); however, the proboscis structure in members of other genera has not been studied by laser scanning confocal microscopy. In Hubrechtella, the pilidium auriculatum larva has a pair of cords ("retractors") attached to the posterior part of the helmet wall (Chernyshev, 2011), which is a trait probably specific to hubrechtiids.

COMPOSITION. Two families, Hubrechtiidae Bürger, 1892 and Hubrechtellidae Chernyshev, 2003.

Order Heteronemertea Bürger, 1892

DIAGNOSIS. Body-wall musculature consists of outer longitudinal, outer circular, and middle longitudinal muscle layers; inner circular layer present in some species. Cutis present (except Riserius Norenburg, 1993 and Colemaniella Gibson, 1982). Brain and lateral nerve cords located between body-wall outer longitudinal and outer circular musculature. Monociliary sensory cells of proboscis with apical cylinder.

SYNAPOMORPHIES. Cutis and outer longitudinal musculature in the body wall; apical 
cylinder in the monociliary sensory cells of proboscis.

COMPOSITION. To date, several classifications have been proposed for the order on the family level (Gibson, 1982, 1985; Chernyshev, 1995, 2011). Molecular phylogenetic analyses of heteronemerteans do not support segregation of the families Cerebratulidae Gibson, 1985 and Gorgonorhynchidae Gibson, 1985 (Chernyshev, Polyakova, 2019; Hookabe et al., 2021). According to recent data, the genus Polydendrorhynchus Yin et Zeng, 1988 belongs to clade Cerebratulus (Hookabe et al., 2021), and, therefore, placing the close genus Polybrachiorhynchus Gibson, 1977 into the family Polybrachiorhynchidae Gibson, 1985 (=Polybranchiorhynchidae) is unjustified. The family Myxolineidae Gibson, 1985 was erected on the basis of three muscular layers (outer circular, middle longitudinal, and inner circular) in proboscis (Gibson, 1985). Nevertheless, it has been shown that all nemerteans have the inner circular musculature present in proboscis (Magarlamov, Chernyshev, 2015). The genus Riserius, placed in the family Riseriidae Chernyshev, 1995, belongs to Lineidae, as evidenced by a molecular phylogenetic analysis (Hiebert, 2016). According to our unpublished phylogenetic data, the genus Paralineopsis Iwata, 1993, which has been segregated into the family Paralineidae Chernyshev, 1995 along with the genus Paralineus Schütz, 1911, is close to the Riserius. A molecular phylogenetic analysis supports validity of two families: Valenciniidae Hubrecht, 1879 and Lineidae McIntosh, 1874 (Chernyshev, Polyakova, 2018, 2019). Sequences for Poliopsis lacazei Joubin, 1890 have not yet been obtained. However, the morphology of this species is very unusual, which suggests that the family Poliopsidae Gibson, 1982 should currently be accepted as valid.

\section{Class Hoplonemertea Hubrecht, 1879}

DIAGNOSIS. Mouth located in brain region, anteriorly to it, or opens into rhynchodaeum. Caudal cirrus absent. Epidermis of hoplonemertean type. Body-wall musculature consists of outer circular, diagonal, and longitudi- nal muscle layers; inner circular layer present in some species. Brain and lateral nerve cords located inside body-wall inner longitudinal body musculature. Proboscis radial, without diagonal musculature, and with stylet apparatus in middle portion (except some symbiotic species). Pseudocnidae absent. Spermatozoa with single ring-shaped mitochondrion. Decidula larva.

SYNAPOMORPHIES. Hoplonemertean epidermis with basal-cup zone (Norenburg, 1985); submuscular position of the brain and lateral nerve cord; radial proboscis; and stylet apparatus.

\section{Order Polystilifera Brinkmann, 1917}

DIAGNOSIS. Stylet apparatus of polystiliferous type. Bulb region weakly developed, with endothelial circular muscles and without crisscrossed musculature.

SYNAPOMORPHIES. Polystiliferous stylet apparatus. The monostiliferous stylet apparatus is usually derived from the polystiliferous stylet apparatus (see Stricker, 1985), but different structure of the musculature, however, indicates the independent origins of the two (Chernyshev, 2015).

REMARKS. For more than 100 years, Polystilifera was divided into two groups, Reptantia and Pelagica (Brinkmann, 1917), which have recently been considered as suborders. A recent molecular phylogenetic analysis has shown that clade Pelagica originated from deepsea Reptantia (Chernyshev, Polyakova, 2019), i.e., Reptantia is a paraphyletic group. In this regard, the previous division of Polystilifera into suborders and infraorders seems phylogenetically unsubstantiated.

COMPOSITION. Different authors distinguish from 5 to 10 families of benthic and from 3 to 12 families of pelagic polystiliferous nemerteans (see Chernyshev, 2011). Molecular phylogenetic analysis of Polystilifera does not yet allow a revision of the classification of the order on the family level.

Order Monostilifera Brinkmann, 1917

DIAGNOSIS. Stylet apparatus of monostiliferous type or reduced. Bulb region well- 
developed, without endothelial circular muscles and with crisscrossed musculature.

SYNAPOMORPHIES. Monostiliferous stylet apparatus; bulb region with crisscrossed musculature.

Suborder Cratenemertea Chernyshev, 2003

DIAGNOSIS. Cerebral organs completely or partly located posteriorly to brain, with their canals bifurcated. Cephalic furrow well-developed, frequently with secondary grooves. Rhynchocoel wall consists of interwoven musculature.

SYNAPOMORPHIES. It was previously assumed that the synapomorphy of Cratenemertea is interwoven rhynchocoel musculature (Chernyshev, 2011). However, new data on hoplonemertean phylogeny (Chernyshev, Polyakova, 2019) suggests that interwoven rhynchocoel musculature in Polystilifera is in the plesiomorphous state, and, thus, we cannot yet ascertain which state is plesiomorphous for Monostilifera (see Kajihara, 2021).

REMARKS. The name Cratenemertea was proposed as a clade without diagnosis (Thollesson, Norenburg, 2003) and, in the same year, as order with diagnosis (Chernyshev, 2003).

COMPOSITION. Families Cratenemertidae Friedrich, 1968, Uniporidae Stiasny-Wijnhoff, 1936, and Korotkevitschiidae Chernyshev, 2003.

Suborder Eumonostilifera Chernyshev, 2003

DIAGNOSIS. Cerebral organs located in brain region or anteriorly to it, with their canals simple or bifurcated. Cephalic furrows developed to various extents, may be absent, without secondary grooves. Rhynchocoel wall consists of two muscle layer or interwoven musculature.

SYNAPOMORPHIES. The position of the cerebral organs, which do not extend behind the brain can be a possible synapomorphy of the suborder.

Infraorder Amphiporina Chernyshev et Polyakova, 2019 emend. Kajihara, 2021

DIAGNOSIS. Rhynchocoel wall with two (inner longitudinal and outer circular) muscular layers (except Malacobdella Blainville, 1827). Blood system with single vascular plug or vascular plug absent.

SYNAPOMORPHIES. The two-layered muscular rhynchocoel wall is probably a syna- pomorphy of this infraorder, but, if this interpretation is correct, the same structure of the rhynchocoel wall appeared in the infraorder Oerstediina (Kajihara, 2021).

REMARKS. Clade Amphiporina was established without diagnosis, but with indication of the infraorder rank (Chernyshev, Polyakova, 2019: 15). Kajihara (2021) provided a diagnosis for this infraorder.

COMPOSITION. Molecular phylogenetic analysis of Amphiporina does not y et allow a revision of the classification of the infraorder on the family level. Most families included in this infraorder (Amphiporidae Oersted, 1843, Emplectonematidae Bürger, 1904, Tetrastemmatidae Hubrecht, 1879, Prosorhochmidae Bürger, 1895, Poseidonemertidae Chernyshev, 2002, etc.) as currently constituted in recent classifications, have been shown to be polyphyletic in recent molecular analyses; some of the families (Prostomatidae Bürger, 1904, Malacobdellidae Blanchard, 1847, and Zygonemertidae Chernyshev, 2005) are not phylogenetically isolated from the other members of the infraorder to an extent great enough to consider them independent (e.g., Malacobdella Blainville, 1827 is a sister group to the genus Geonemertes Semper, 1863).

Infraorder Oerstediina Chernyshev et Polyakova, 2019 emend. Kajihara, 2021

DIAGNOSIS. Rhynchocoel wall with two (inner longitudinal and outer circular) or one (interwoven) muscular layers. Blood system with pair of vascular plugs.

SYNAPOMORPHIES. Two vascular plugs.

REMARKS. Clade Oerstediina was established without diagnosis, but with indication of the infraorder rank (Chernyshev, Polyakova, 2019: 15). Kajihara (2021) provided a diagnosis for this infraorder.

COMPOSITION. Families Plectonemertidae Gibson, 1990 s.l. and Oerstediidae Chernyshev, 1993 s.l.

\section{Nemertea incertae sedis}

Order Arhynchonemertea Chernyshev, 1995

DIAGNOSIS. Rhynchocoel and proboscis absent. Blood system simple, without middor- 
sal vessel. Mouth located in brain region. Brain with single commissura. Brain and lateral nerve cords located inside inner longitudinal musculature. One ventral nephridium behind mouth.

REMARKS. The only species of this order, Arhynchonemertes axi Riser, 1988, is distinguished from all other nemerteans by the lack of rhynchocoel and proboscis, despite the fact that this nemertean is free-living. The position of the nervous system is similar to that of hoplonemerteans, but the structure of its digestive system is similar to that of palaeonemerteans. Chernyshev (1995) segregated $A$. axi into a separate class, Arhynchocoela. No sequence data are available for $A$. axi to date.

COMPOSITION. Family Arhynchonemertidae Chernyshev, 1995.

\section{Acknowledgements}

I am grateful to Evgeniy P. Shvetzov for correcting the English text. Jon Norenburg is owed special thanks for constructive criticism that improved the manuscript.

\section{References}

Andrade S.C.S., Strand M., Schwartz M., Chen H.-X., Kajihara H., von Döhren J., Sun S., Junoy J., Thiel M., Norenburg J.L., Turbeville J.M., Giribet G., Sundberg P. 2012. Disentangling ribbon worm relationships: multi-locus analysis supports traditional classification of the phylum Nemertea // Cladistics. Vol.28. P.141-159.

Andrade S.C., Montenegro H., Strand M., Schwartz M., Kajihara H., Norenburg J.L., Turbeville J.M., Sundberg P., Giribet G. 2014. A transcriptomic approach to ribbon worm systematics (Nemertea): resolving the Pilidiophora problem // Mol. Biol. Evol. Vol.31. P.3206-3215.

Brinkmann A. 1917. Pelagic nemerteans from the "Michael Sars" North Atlantic Deep-Sea Expedition 1910 // Rep. Sci. Res. "Michael Sars" North Atlantic DeepSea Exped. 1910. Vol.3. No.2. P.1-18.

Bürger O. 1892. Zur Systematik der Nemertinenfauna des Golfs von Neapel // Nachr. König. Ges. Wiss. GeorgAugusts-Univ. Göttingen. Bd.5. S.137-178.

Chernyshev A.V. 1995. [On the higher taxa of the phylum Nemertea with the taxonomic review of the subclass Anopla] // Zool. Zhurn. Vol.74. No.1. P.7-18 [in Russian, with English summary].

Chernyshev A.V. 1999. [Nemertines of the family Carinomidae (Nemertea, Anopla). 2. Origin and taxonomic position of Carinomidae] // Zool. Zhurn. Vol.78.
No.12. P.1407-1416 [in Russian with English abstract].

Chernyshev A.V. 2003. Classification system of the higher taxa of enoplan nemerteans (Nemertea, Enopla) // Russ. J. Mar. Biol. Vol. 29. Suppl.1. P.S57-S65.

Chernyshev A.V. 2011. [Comparative morphology, systematics and phylogeny of the nemerteans]. Dalnauka: Vladivostok. 309 p. [In Russian]

Chernyshev A.V. 2015. CLSM analysis of the phalloidinstained muscle system of the nemertean proboscis and rhynchocoel // Zool. Sci. Vol.32. P.547-560.

Chernyshev A.V., Polyakova N.E. 2018. Nemerteans from deep-sea expedition SokhoBiol. with description of Uniporus alisae sp. nov. (Hoplonemertea: Reptantia s.1.) from the Sea of Okhotsk // Deep Sea Res. Part II Top. Stud. Oceanogr. Vol.154. P.121-139.

Chernyshev A.V., Polyakova N.E. 2019. Nemerteans from the deep-sea expedition KuramBio II with descriptions of three new hoplonemerteans from the KurilKamchatka Trench // Prog. Oceanogr. Vol.178. Art. 102148.

Chernyshev A.V., Magarlamov T.Y., Turbeville J.M. 2013. Morphology of the proboscis of Hubrechtella juliae (nemertea, pilidiophora): implications for pilidiophoran monophyly// J. Morph. Vol.274. P.13971414 .

Chernyshev A.V., Polyakova N.E., Hiebert T.C., Maslakova S.A. 2021. Evaluation of the taxonomic position of the genus Carinina (Nemertea: Palaeonemertea), with descriptions of two new species // Invertebr. Syst. Vol.35. P.245-260.

Crandall F.B. 1993. Major characters and enoplan systematics // Hydrobiologia. Vol.266. P.115-140.

Gibson R. 1982. Nemertea // Parker S.P. (ed.). Synopsis and Classification of Living Organisms. Vol.1. New York: McGraw-Hill. P.823-846.

Gibson R. 1985. The need for a standard approach to taxonomic descriptions of nemerteans // Am. Zool. Vol.25. P.5-14.

Gibson R. 1988. Evolutionary relationships between monoand polystiliferous hoplonemerteans Nipponnemertes (Cratenemertidae), a "missing link" genus? // Hydrobiologia. Vol.156. P.61-74.

Gibson R. 1995. Nemertean genera and species of the world: an annotated checklist of original names and description citations, synonyms, current taxonomic status, habitats and recorded zoogeographic distribution // J. Nat. Hist. Vol.29. P.271-562.

Hiebert T.C. 2016. New nemertean diversity discovered in the Northeast Pacific using surveys of both planktonic larvae and benthic adults. PhD thesis. Univ. Oregon. $402 \mathrm{p}$.

Hookabe N., Xu C.-M., Tsuyuki A., Jimi N., Sun S.-C., Kajihara H. 2021. A new nemertean with a branched proboscis, Gorgonorhynchus citrinus sp. nov. (Nemertea: Pilidiophora), with molecular systematics of the genus// Invert. Syst. Vol.35. P.350-359.

Kajihara H. 2007. A taxonomic catalogue of Japanese nemerteans (phylum Nemertea) // Zool. Sci. Vol.24. P.287-326. 
Kajihara H. 2021. Higher classification of the Monostilifera (Nemertea: Hoplonemertea) // Zootaxa. Vol. 4920. No.2. P.151-199.

Kajihara H., Chernyshev A.V., Sun S., Sundberg P., Crandall F.B. 2008. Checklist of nemertean genera and species (Nemertea) published between 1995 and 2007 // Species Divers. Vol.13. P.245-274.

Kvist S., Laumer C.E., Junoy J., Giribet G. 2014. New insights into the phylogeny, systematics and DNA barcoding of Nemertea // Invert. Syst. Vol.28. P.287308.

Kvist S., Chernyshev A.V., Giribet G. 2015. Phylogeny of Nemertea with special interest in the placement of diversity from Far East Russia and northeast Asia // Hydrobiologia. Vol.760. No.1. P.105-119.

Magarlamov T.Yu., Chernyshev A.V. 2015. Structure of the proboscis endothelium in Nemertea // Zool. Sci. Vol.32. P.561-566.

Magarlamov T.Yu., Turbeville J.M., Chernyshev A.V. 2021. Pseudocnidae of ribbon worms (Nemertea): ultrastructure, maturation, and functional morphology // PeerJ. 9. e10912

Norenburg J.L. 1985. Structure of the nemertine integument with consideration of its ecological and phylogenetic significance // Amer. Zool. Vol.25. P.37-51.

Norenburg J., Gibson R., Herrera Bachiller A., Strand M. 2021. World Nemertea Database. Carinomiformes. Accessed through: World Register of Marine Species at: http://www.marinespecies.org/aphia.php?p= taxdetails\&id=1451615 on 2021-05-09

Stiasny-Wijnhoff G. 1936. Die Polystilifera der SibogaExpedition // Siboga Exped. Bd.22. S.1-214.
Strand M., Norenburg J., Alfaya J.E., Fernández-Álvarez F.Á., Andersson H.S., Andrade S.C.S., Bartolomaeus T., Beckers P., Bigatti G., Cherneva I., Chernyshev A., Chung B.M., von Döhren J., Giribet G., GonzalezCueto J., Herrera-Bachiller A., Hiebert T., Hookabe N., Junoy J., Kajihara H., Krämer D., Kvist S., Magarlamov T.Yu., Maslakova S., Mendes C.B., Okazaki R., Sagorny C., Schwartz M., Sun S.-C., Sundberg P., Turbeville J.M., Xu C.-M. 2019. Nemertean taxonomy - implementing changes in the higher ranks, dismissing Anopla and Enopla // Zool. Scr. Vol.48. P.118-119.

Stricker S.A. 1985. The stylet apparatus of monostiliferous hoplonemerteans // Am. Zool. Vol.25. P.87-97.

Sundberg P. 1991. A proposal for renaming the higher taxonomic categories in the phylum Nemertea // J. Nat. Hist. Vol.25. P.45-48.

Thollesson M., Norenburg J.L. 2003. Ribbon worm relationships: A phylogeny of the phylum Nemertea // Proc. R. Soc. Lond. (Biol). Vol.270. P.407-414.

Wijnhoff G. 1913. Die Gattung Cephalothrix und ihre Bedeutung für die Systematik der Nemertinen. II. Systematischer Teil // Zool. Jb., Abt. Syst. Ökol. Geogr. Tiere. Bd.34. S.291-320.

Yurchenko O.V., Neznanova S.Yu., Chernyshev A.V. 2021. A comparative morphological study of the testes, spermatogenesis and spermatozoa in two nemertean species, Callinera sp. and Parahubrechtia sp. (Palaeonemertea, Tubulanidae) // Zool. Anz. Vol.294. P.114-127.

Responsible editor A.S. Petrunina 